\title{
Water for maize for pigs for pork: An analysis of inter-provincial trade in China
}

\author{
La Zhuo a, b, *, Yilin Liu a , Hong Yang ${ }^{\text {c, d }}$, Arjen Y. Hoekstra ${ }^{\text {e, g, Wenfeng Liu }}{ }^{\text {c, f }}$, \\ Xinchun Cao ${ }^{\mathrm{h}}$, Mengru Wang ${ }^{\mathrm{i}}$, Pute $\mathrm{Wu}^{\mathrm{a}, \mathrm{b}, * *}$ \\ ${ }^{a}$ Northwest A \& F University, Yangling, 712100, China \\ ${ }^{\mathrm{b}}$ Institute of Soil and Water Conservation, Chinese Academy of Sciences \& Ministry of Water Resources, Yangling, 712100, China \\ ${ }^{\mathrm{c}}$ Eawag, Swiss Federal Institute of Aquatic Science and Technology, Duebendorf, $\mathrm{CH}-8600$, Switzerland \\ ${ }^{\mathrm{d}}$ Department of Environmental Sciences, MGU, University of Basel, Basel, $\mathrm{CH}-4003$, Switzerland \\ e Twente Water Centre, University of Twente, P.O. Box 217, Enschede, 7500AE, the Netherlands \\ ${ }^{\mathrm{f}}$ Laboratoire des Sciences du Climat et de l'Environment, LSCE/IPSL, CEA-CNRS-UVSQ Université Paris-Saclay, F-91191, Gif-sur-Yvette, France \\ ${ }^{\mathrm{g}}$ Institute of Water Policy, Lee Kuan Yew School of Public Policy, National University of Singapore, 259770, Singapore \\ ${ }^{\text {h }}$ Hohai University, Nanjing, 210098, China \\ ${ }^{\mathrm{i}}$ Water Systems and Global Change Group, Wageningen University \& Research, Wageningen, 6708 PB, the Netherlands
}

\section{A R T I C L E I N F O}

\section{Article history:}

Received 23 March 2019

Received in revised form

3 September 2019

Accepted 9 September 2019

Available online 9 September 2019

\section{Keywords:}

Pork

Maize

Supply chain

Water footprint

Virtual water trade

\begin{abstract}
A B S T R A C T
Trade in commodities implies trade in virtual water (VW), which refers to the water that was used to produce the traded goods. Various studies have quantified international or inter-provincial virtual water (VW) flows related to the trade in crops and animal products. Until date, however, no effort has been undertaken to understand how the water embodied in traded feed crops (trade stage TS1) will be transferred further because of trade in animal products (trade stage TS2). This is the first study showing this mechanism, in a case study in China for maize (the major pig feed) and pork (the dominant meat), considering the period 2000-2013. We estimate the annual green and blue water footprints in maize production and then quantify the inter-provincial VW flows related to trade in maize (TS1) and trade in maize embodied in pork (TS2). Results show that in TS1, maize-related VW flowed from the water-scarce North to the water-rich South, with an increase of $40 \%$ over the study period (from 43 to 61 billion $\mathrm{m}^{3}$ $\mathrm{y}^{-1}$ ). In TS2, about $10 \%$ of the water embodied in maize exports from North to South China returns in the form of pork, with an increase in the absolute amount of $25 \%$ (from 4.8 to 6.1 billion $\mathrm{m}^{3} \mathrm{y}^{-1}$ ). Considering blue VW flows specifically, we find that North-to-South blue VW flows decreased by $5 \%$ in TS1, while South-to-North blue VW flows increased by 23\% in TS2.
\end{abstract}

(c) 2019 The Authors. Published by Elsevier Ltd. This is an open access article under the CC BY-NC-ND license (http://creativecommons.org/licenses/by-nc-nd/4.0/).

\section{Introduction}

Trade in goods and services among nations and within a nation implies long-distance socioeconomic and environmental interactions, introducing a global dimension to the challenge of sustainable use of natural resources (Liu et al., 2013). Trade can compensate for natural resource deficits in importing regions and create labour opportunities and economic outputs in the exporting regions. But trade may also shift the burden of resource use and

\footnotetext{
* Corresponding author. Northwest A \& F University, Yangling, 712100, China.

** Corresponding author. Institute of Soil and Water Conservation, Chinese Academy of Sciences \& Ministry of Water Resources, Yangling, 712100, China.

E-mail addresses: zhuola@nwafu.edu.cn (L. Zhuo), gjzwpt@vip.sina.com (P.Wu).
}

environmental impacts from the importing region where the consumption takes place to the exporting region where the production is located (Wiedmann and Lenzen, 2018; Sun et al., 2018; Pace and Gephart, 2017; Zhao et al., 2016; Dalin and Rodríguez-Iturbe, 2016; Yang et al., 2006). Globally, around $10-70 \%$ of environmental influences (e.g. $\mathrm{CO}_{2}$ emissions, particulate matter emissions, land use, coal exploitation, and water consumption) are embodied in the international trade, in which food trade has been the dominant driver (Wiedmann and Lenzen, 2018). Here, we are interested in the consumption of water for producing food, whereby we will focus on the case of 'water for maize for pigs for pork'. This includes two stages of trade: trade in maize and trade in pork. We will trace how the water embodied in traded maize will be transferred further because of trade in pork. 
As a metric for water use we will employ the consumptive water footprint (WF), which measures both consumption of green water (rainwater) and blue water (groundwater and surface water) (Hoekstra, 2017). The external WF of a community within a geographic region refers to the water embodied in its consumption from imports. The water virtually embedded in traded commodities is known as virtual water (VW) (Allan, 2003). Agricultural products together account for $92 \%$ of the WF of humanity, and, more specifically, animal products together contribute about $30 \%$ (Hoekstra and Mekonnen, 2012). The major share (98\%) of the WF of animal products comes from the water consumed to produce the feed (Mekonnen and Hoekstra, 2012). Growing food demand and intensified food trade are increasing the water scarcity in the exporting production regions. Globally, the water depletion in countries scarce in blue water contributed to $35 \%$ of global VW flows (Lenzen et al., 2013) and 11\% of non-renewable groundwater consumption was embodied in the food trade (Dalin et al., 2017).

In this study we distinguish two trade stages of maize (Fig. 1): in the first trade stage (TS1), maize is traded from the place of cultivation to the place of consumption in the form of food by humans or feed by animals; in the second trade stage (TS2), pork is traded from the place of pig farming to the place of pork consumption. We quantify VW flows related to maize trade (TS1) as well as VW flows related to pork trade (TS2). In the latter case we merely focus on the water consumed to produce the maize eaten by the pig to produce one $\mathrm{kg}$ of pork. The new element of the current study is that it maps and links VW flows related to both TS1 and TS2. Inter-regional VW flows redistribute water through trade of water-intensive products and reshaping the patterns of water reliance through teleconnections between the consumers and producers (Zhao et al., 2015; D'Odorico et al., 2019). Severe water scarcity in a certain place can be driven remotely by its trade partner who imports products that consume considerable volume of water in the exporting place. Therefore, it is of importance to clearly and correctly identify the directions and magnitudes of the burden shifting along the VW flows and associated water scarcities. There are numerous studies that map VW flows associated with crop trade (TS1), at global level (e.g., Hoekstra and Mekonnen, 2012; Dalin et al., 2012; Konar et al., 2011) as well as the national level (e.g. Liu et al., 2008; Novo et al., 2009) and sub-national level (e.g. Guan and Hubacek, 2007; Ma et al., 2006; Verma et al., 2009; Dalin et al., 2014; Zhao et al., 2015; Zhuo et al., 2016a; Zhao et al., 2017). There are also several studies that analyse VW flows associated with trade in animal products (TS2) (Hoekstra and Mekonnen, 2012; Ma et al., 2006; Dalin et al., 2014; Hanasaki et al., 2010), but the VW flows related to TS1 and TS2 are never connected. The previous studies on crop-related or food-related VW flow
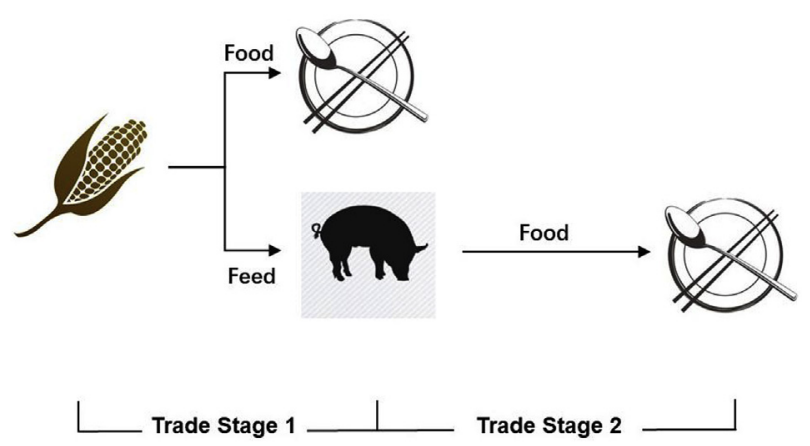

Fig. 1. Two trade stages of maize: in the first stage, maize is traded from the place of cultivation to the place of consumption in the form of food by humans or feed by animals; in the second stage, pork is traded from the place of pig farming to the place of pork consumption. assessments ignore the effects of ST2 as well as of the other big crop consumer, livestock, than humanity on such burden shifting among trade partners.

Here we choose maize and pork trade among provinces in China in the period 2000-2013 as a study case. The pork consumer indirectly consumes the maize for feeding the pigs. Whereas previous studies that quantify VW flows related to trade in pork consider the full amount of embodied water in traded pork, we are interested here only in the maize-related embodied water in traded pork. We first estimate the green and blue WFs of maize production in China per year over the period 2000-2013 at a $5 \times 5$ arc-minute grid level with consideration of the effects of different irrigation techniques. Second, we quantify the inter-provincial VW flows within China related to trade in maize. Third, we quantify the interprovincial VW flows related to the pork trade, considering specifically the water-for-maize-for-pig-for-pork.

Maize is one of the major feed crops in the world and contributes $17 \%$ to the WF of the global livestock sector (Mekonnen and Hoekstra, 2012). China is currently the second biggest producer of maize in the world, responsible for $22 \%$ of global maize production (2016). About $70 \%$ of maize utilization in China is for feed (FAO, 2018). Over the period 2000-2013, maize demand for feed in China increased by $69 \%$, the harvested area of maize by $57 \%$ and total maize production by 106\% (NBSC, 2018). China is the world's largest pork producer, accounting for $48 \%$ of the global total (FAO, 2018). We choose inter-provincial trade of maize and pork in China as a representative target with three main reasons: Firstly, China has intensive inter-provincial transfers of maize which resulted in visible maize-related water scarce North-to- water rich South VW flows. Inter-regional maize-related VW flows contributed to $39 \%$ of the crop-related North-to-South VW flows (i.e. the biggest contributor among considered crops) and 38\% of croprelated gross VW flows within China by 2008 (Zhuo et al., 2016a). Secondly, in China's maize-related inter-provincial VW flows, 72\% was driven by feed consumption (2013) (FAO, 2018). Given China is the world biggest pork producer with much higher stock than other types of livestock, majority of maize feed consumption is for pigs. Thirdly, there is significant spatial mismatch between feed and pork production (Fig. 2) as well as between the consumption and production of pork. In 2013, North China produced $84 \%$ of the national maize production, while South China accounted for $60 \%$ of the country's pork production (NBSC, 2018).

Given the high water scarcity in North China, there is much interest in understanding the reasons and dynamics underlying the widely reported North-to-South VW flows related to agricultural products (mainly crops) based on either the bottom-up approach (i.e. food balance methods) (Ma et al., 2006; Dalin et al., 2014; Zhuo et al., 2016a; Wu et al., 2010; Cao et al., 2011; Dong et al., 2014; Sun et al., 2019), or top-down approach (i.e. Input-output models) (Guan and Hubacek, 2007; Feng et al., 2014; Zhao et al., 2015, 2019, 2018; Zhang and Anadon, 2014). The VW export from North China is increasingly recognized as one of the key contributions to local water scarcity (Feng et al., 2014; Zhao et al., 2018; Hoekstra and Mekonnen, 2016; Chukalla et al., 2015). Compared to the studies based on bottom-up approaches, the common conclusion is the main direction of the North-to-South VW flows within China. With a full picture covering all the water using sectors, the top-down method based studies were able to map the patterns and construction of the VW flows (Zhang and Anadon, 2014; Guan and Hubacek, 2007; Zhao et al., 2015), scarce (unsustainable) virtual flows (Feng et al., 2014; Zhao et al., 2018) and the driving factors (Zhao et al., 2019). However, none has solved the current research question on distinction and links between VW flows in ST1 and ST2. Currently, China has the world largest amount of non-renewable groundwater depletion related to maize production $(\sim 4.7$ million 


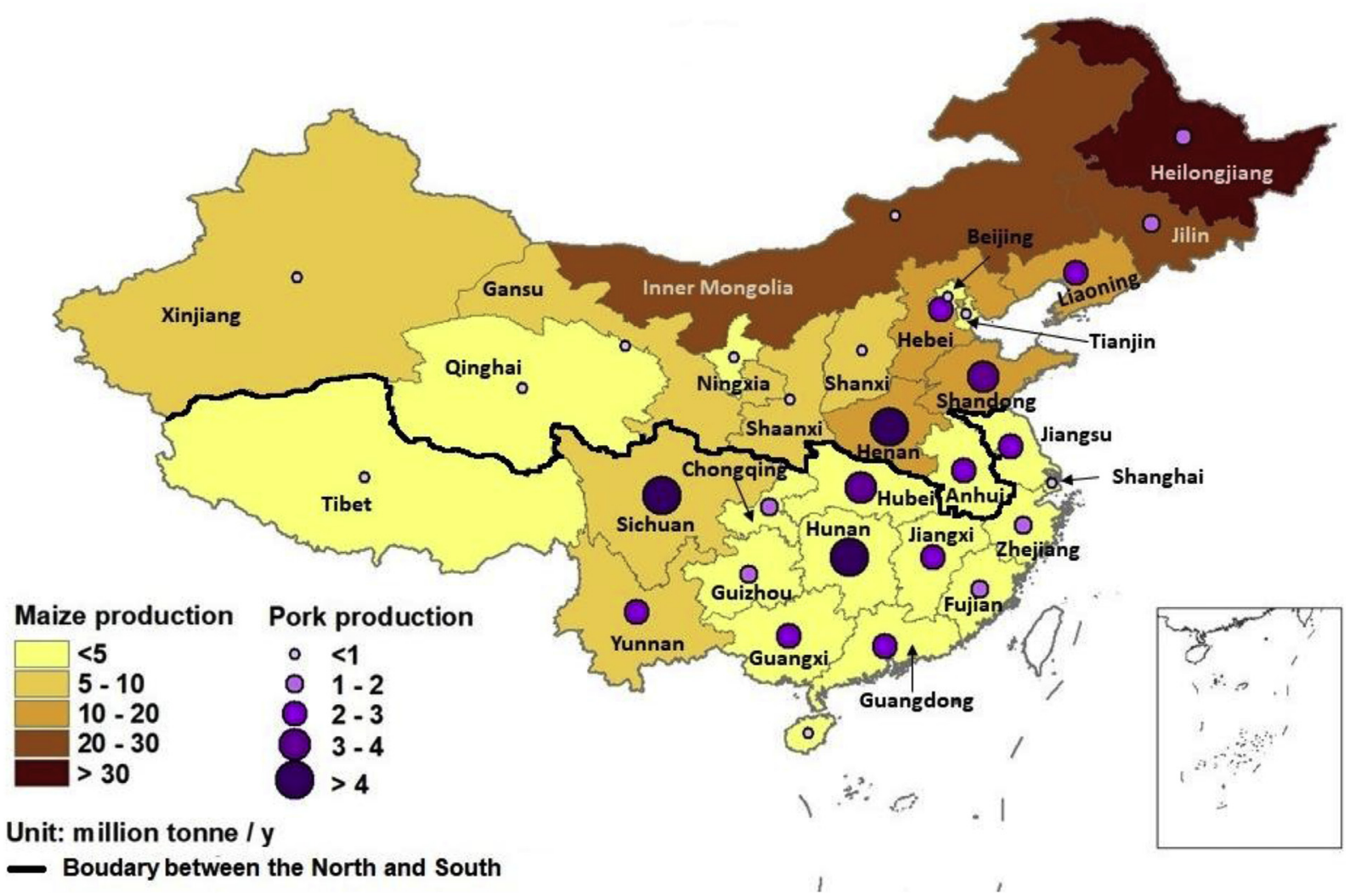

Fig. 2. Maize and pork production per province in China 2013. Data source: NBSC (2018).

$\mathrm{m}^{3} \mathrm{y}^{-1}$ ), most of which is in the North (Dalin et al., 2017).

\section{Methods and data}

\subsection{Estimating green and blue WFs of maize}

We distinguish between the water footprint of production of maize in a province and the average water footprint of maize as available on the market in a province. The latter is used for estimating the WF of the maize fed to pigs and finally the WF of pork, assuming that pigs consume a mix of domestically produced maize and maize imported from other provinces according to the relative proportions available in a province. The average green and blue WFs of rainfed and irrigated maize production per province over the study period 2000-2013 were based on estimation at $5 \times 5$ arcminute grid level following the accounting framework of Hoekstra et al. (2011). The green and blue WFs of maize production $\left(\mathrm{m}^{3} \mathrm{t}^{-1}\right)$ within a grid cell were calculated as the actual green and blue evapotranspiration (ET, $\mathrm{m}^{3} \mathrm{t}^{-1}$ ) over the growing period divided by the crop yield ( $\mathrm{Y}, \mathrm{t} \mathrm{ha}{ }^{-1}$ ). FAO's crop water productivity model AquaCrop version 6.0 (Steduto et al., 2009; Raes et al., 2009; Hsiao et al., 2009) was used to simulate ET and Y per grid cell per year. The simulated maize yields in all grid cells in a province were scaled to fit to the statistics on maize production at province level (Zhuo et al., 2016b). The separation of green and blue ET was carried out by tracking the daily green and blue soil water balances based on the contribution of rainfall and irrigation, respectively, following Chukalla et al. (2015), Zhuo et al. (2016b) and Karandish and Hoekstra (2017).

Regarding irrigated maize production, we simulated the WFs under three different irrigation methods: furrow, sprinkler and micro irrigation. In AquaCrop, the effects of varied irrigation are reflected by the different levels of soil evaporation (E), which partially depends on the fraction of soil surface wetted $\left(f_{w}, \%\right)$ during irrigation, which different by irrigation method (Allen et al., 1998). Soil evaporation (E) is calculated by multiplying the reference evapotranspiration with the soil evaporation coefficient (Ke) which considers the characteristics of soil surface and the fraction of the soil surface not covered by the canopy. When considering the effects of different irrigation methods that the soil surface is partially wetted, the Ke is adjusted by the fraction of the surface wetted $\left(f_{w}\right)$ (Allen et al., 1998).

$K e=f_{w} \times\left(1-C C^{*}\right) \times K e_{x}$

where $C C^{*}$ refers to the canopy cover fraction, $\mathrm{Ke}_{\mathrm{x}}$ maximum soil evaporation coefficient for fully wet and not shaded soil surface. We set values of $\mathrm{f}_{\mathrm{w}}$ as $80 \%, 100 \%$ and $40 \%$ for furrow, sprinkler and micro irrigation, respectively. For each grid, the overall green and blue WF $\left(W F_{g}\right.$ and $\left.W F_{b}, \mathrm{~m}^{3} \mathrm{t}^{-1}\right)$ of irrigated maize then can be calculated as:

$W F_{g}=\frac{\sum_{i=1}^{3}\left(10 \times \sum_{t=1}^{g p} E T_{g}(t, i) \times w(i)\right)}{\sum_{i=1}^{3}(Y(i) \times w(i))}$

$W F_{b}=\frac{\sum_{i=1}^{3}\left(10 \times \sum_{t=1}^{g p} E T_{b}(t, i) \times w(i)\right)}{\sum_{i=1}^{3}(Y(i) \times w(i))}$

where i refers to the irrigation method and $w(i)$ to the percentage of irrigation method $i$ in the total irrigated area of maize in the grid cell. Since percentages $w(i)$ are available only by province, we assume $w(i)$ per grid cell equal to the value at province level. Evapotranspiration (ET) is summed over the days of the growing period ( $g p)$. 


\subsection{Estimating green and blue WFs of maize in pork}

For estimating the volume of water-for-maize-for-pig-for-pork, we first estimate the amount of maize embodied in $1 \mathrm{~kg}$ of pork. The amount of maize is then multiplied with the green and blue WFs of maize to obtain the green and blue WFs per kg of pork related to the maize eaten by the pig.

The maize embodied in pork, which we will call here the virtual maize content of pork (VMC, $\mathrm{kg} \mathrm{kg}^{-1}$ ) equals the maize fed to pig over its lifetime (maize consumption $M C, \mathrm{~kg}$ head $^{-1}$ ) divided by the pork-production rate per pig $\left(p p r, \mathrm{~kg} \mathrm{head}^{-1}\right)$. Here we assume that China's national total maize feed goes to swine farms, with two reasons. Firstly, pigs are the only livestock with maize-dominated feeding. Maize is responsible for over 63\% in pig feeding (Hansen, 2007). Secondly, pigs dominate China's livestock industry fed by maize; in 2013, the number of pigs in China was four times higher than the number of goats, the second largest livestock category (NBSC, 2018). The WF of per $\mathrm{kg}$ of the VMC per province refers to the average WF of maize as on the market in the province (i.e. the $W F_{\text {cons }}$ shown in equation (3)). The WF of maize on the market in a province depends on the ratio of provincially produced maize to imported maize and the WFs in the respective locations of production. The average WF of the maize consumed in a province $\mathrm{i}$ $\left(W F_{\text {cons }}(i), \mathrm{m}^{3} \mathrm{t}^{-1}\right)$ and is calculated as follows:

$W F_{\text {cons }}(i)=\frac{P(i) \times W F_{\text {prod }}(i)+\sum_{e}\left(I(e) \times W F_{\text {prod }}(e)\right)}{P(i)+\sum_{e} I(e)}$

in which $P(i)\left(\mathrm{t}^{-1}\right)$ refers to the maize production quantity in province $\mathrm{i}, I(e)\left(\mathrm{t}^{-1}\right)$ to the imported quantity of maize from exporting place e (other regions in China or other countries outside China), $W F_{\text {prod }}(i)\left(\mathrm{m}^{3} \mathrm{t}^{-1}\right)$ the WF per unit of maize in province $\mathrm{i}$, and $W F_{\text {prod }}(e)\left(\mathrm{m}^{3} \mathrm{t}^{-1}\right)$ the $W F$ per unit of maize as produced in exporting place $\mathrm{e}$.

\subsection{Estimating inter-provincial VW networks related to trade in maize and pork}

The VW flow in TS1 was calculated by multiplying the related maize trade flow $\left(\mathrm{t} \mathrm{y}^{-1}\right)$ with the WF of maize production $\left(\mathrm{m}^{3} \mathrm{t}^{-1}\right)$ in the exporting region. The VW flow in TS2 was computed as the product of the pork trade flow $\left(\mathrm{t}^{-1}\right)$, the amount of maize
We estimate provincial trade balances (i.e. net imports) for maize and pork as the consumption in a province minus the production in a province (Ma et al., 1998; Zhuo et al., 2016a), with consideration of international trade, production, consumption of maize for food, feed, and manufactured products as well as waste and seed based on the national food balance sheets in FAOSTAT (FAO, 2018) combined with population and livestock units per province. For each year, the national consumption of maize for direct human consumption and manufactured products, and the national consumption of pork, as given by FAO (2018), were distributed over the provinces based on provincial populations. The national use of maize for feed was distributed over provinces proportional to the amount of pigs per province.Provincial statistics on yearly maize and pork production per province were taken from NBSC (2018).

Inter-provincial trade matrices for maize and pork per year were determined by using a linear programming optimization procedure, assuming that inter-provincial trade flows are such that the overall transport cost of trade is minimized (following Dalin et al., 2014). The net import of product $p$ in a province is defined as the total provincial utilization of the product minus the local production. We considered four harbour provinces (Tianjin, Liaoning, Shandong and Guangdong) for distributing foreign imports of maize and pork to provinces and for shipping exports. We assume that the intra-national and international imports occur in deficit provinces where demand is lower than production, and that the intra-national and international exports are from surplus provinces.

We estimate inter-provincial trade of a product $p$ from this objective function:

Minimize:

$$
\begin{aligned}
& T C(p)=\sum_{i=1, j=1, h=1}^{i=31, j=31, h=4}\left(T_{\text {int }}(i, h, p) \times c(i, h)+T_{\text {int }}(h, j, p)\right. \\
& \times c(h, j))+\sum_{i=1, j=1}^{i=31, j=31} T_{l o c}(i, j, p) \times c(i, j)
\end{aligned}
$$

Subject to:

$\forall(i, j) \in[1: 31]$ and $\forall h \in[1: 4]:$

$$
\left\{\begin{array}{l}
\sum_{i=1, j=1}^{i=31, j=31} T_{l o c}(i, j, p)+\sum_{i=1, h=1}^{i=31, h=4} T_{\text {int }}(i, h, p)=P(i, p)-D(i, p), \text { if } P(i, p)>D(i, p) \\
\sum_{j=1, i=1}^{j=31, i=31}(i, j, p)+\sum_{j=1, h=1}^{j=31, h=4} T_{\text {int }}(h, j, p)=D(j, p)-P(j, p), \text { if } P(j, p)>D(j, p) \\
\sum_{i=1, h=1}^{h=4} T_{\text {int }}(i, h, p)=E_{\text {int }}(p) \\
\sum_{h=1, j=31} T_{\text {int }}(h, j, p)=I_{\text {int }}(p) \\
T_{l o c}(i, j, p) \geq 0 \\
T_{\text {int }}(i, h, p) \geq 0, T_{\text {int }}(h, j, p) \geq 0
\end{array}\right.
$$

consumed per unit of pork $\left(\mathrm{kg} \mathrm{kg}^{-1}\right)$ and the WF per tonne of maize $\left(\mathrm{m}^{3} \mathrm{t}^{-1}\right)$ on the market in the pork export region. in which $T C(p)$ (in $C N Y y^{-1}$ ) refers to the total transport cost of the inter-provincial trade in product $p ; T_{\text {int }}(i, h, p)$ the foreign export 
volume from province $i$ through harbour province $h ; T_{\text {int }}(h, j, p)$ (t $\mathrm{y}^{-1}$ ) the foreign import volume through harbour province $h$ to province $j ; T_{l o c}(i, j, p)\left(\mathrm{t}^{-1}\right)$ the net trade of product $p$ from province $i$ to province $j ; c(i, h), c(h, j)$ and $c(i, j)\left(\mathrm{CNY} \mathrm{t}^{-1}\right)$ the unit costs of transport between provinces, which were estimated by applying the "OD cost matrix analysis tool" in ArcGIS while taking the transport cost as the impedance and assuming unit costs of rail, road and sea transport of $0.15,20$ and $0.016 \mathrm{CNY} \mathrm{t}^{-1}$, respectively (Gao et al., 2014); $P(i, p)\left(\mathrm{t}^{-1}\right)$ the production of $p$ in province $i$; $D(i, p)\left(\mathrm{t}^{-1}\right)$ the total demand of product $p$ in province $i$; $E_{\text {int }}(p)$ China's total international export of product $p$; and $I_{\text {int }}(p)\left(\mathrm{t} \mathrm{y}^{-1}\right)$ China's total international import of product $p$.

\subsection{Data}

GIS polygon data for Chinese provinces were obtained from the Surveying and Mapping data sharing network (NASMG, 2010). Data on yearly consumption and international trade in maize and pork for China (in $\mathrm{t}^{-1}$ ) over the period 2000-2013 were obtained from FAO (2018). Data on monthly precipitation, reference evapotranspiration and temperature at a resolution of $30 \times 30$ arc-minute were taken from Harris et al. (2014). Data on irrigated and rainfed areas for each crop at a $5 \times 5$ arc-minute resolution were obtained from Portmann et al. (2010). Annual agriculture statistics on harvested areas and yields of maize, statistics for fed and slaughtered livestock and the associated livestock production, as well as total irrigated area with different irrigation methods per province were obtained from NBSC (2018). Soil texture data were obtained from the ISRIC Soil and Terrain database for China at a scale of 1:1 million (Dijkshoorn et al., 2008). For hydraulic characteristics for each type of soil, the indicative values provided by AquaCrop were used. Data on total soil water capacity (in \% vol) at a spatial resolution of $5 \times 5$ arc minute were obtained from the ISRIC-WISE version1.2 dataset (Batjes, 2012).

\section{Results}

\subsection{WF of maize production in China}

Over the study period 2000-2013, China's national average WF per tonne of maize decreased by $23 \%$, from $955 \mathrm{~m}^{3} \mathrm{t}^{-1}$ (of which $18 \%$ blue WF) in 2000 to $692 \mathrm{~m}^{3} \mathrm{t}^{-1}$ (13\% blue WF) in 2013 (Fig. 3). This was mainly related to the increased national average maize yield, which grew by $31 \%$ (from $4.6 \mathrm{t} \mathrm{ha}^{-1}$ in 2000 to $6.0 \mathrm{t} \mathrm{ha}^{-1}$ in 2013). With the doubled total maize production (from 106 to 218 million $\mathrm{t}^{-1}$ ), the national total WF of maize production increased by $49 \%$ (from 101 billion $\mathrm{m}^{3} \mathrm{y}^{-1}$ in 2000 to 151 billion $\mathrm{m}^{3} \mathrm{y}^{-1}$ in 2013), whereby the green WF increased by $58 \%$ from 83 billion $\mathrm{m}^{3}$ $\mathrm{y}^{-1}$ to 132 billion $\mathrm{m}^{3} \mathrm{y}^{-1}$.

North China had a larger WF per tonne of maize than South China (Fig. 4). The provincial average WF of maize production ranged between $348 \mathrm{~m}^{3} \mathrm{t}^{-1}$ (Qinghai province) and $1032 \mathrm{~m}^{3} \mathrm{t}^{-1}$ (Guizhou province) in 2013. Over the study period, most of the provinces experienced a decrease in the WF per tonne of maize, with an exception for five provinces in the South (Shanghai, Jiangsu, Zhejiang, Hubei and Guizhou). These five provinces also had decreased maize yields. For instance, the maize yield in Guizhou province decreased by $19 \%$ over the study period, while the WF per tonne of maize increased by $31 \%$. For Guizhou province, the reduction started since the year 2011 (with yield level was $42 \%$ less than in 2010) mainly due to the extreme drought happened in August and successive drought problems in the following two years (Wang et al., 2014). In addition, reductions in irrigated maize area (by $30 \%$ in Shanghai and by $3 \%$ in Jiangsu) as well as the less fertilization (by $65 \%$ in Shanghai and by $12 \%$ in Jiangsu) could be other reasons for maize yield decreases (NBSC, 2018). Among all provinces, Inner Mongolia had the highest decrease (59\%) in WF per tonne of maize.

Irrigated maize contributed $48 \%$ to the national total WF of maize production by 2013 , with irrigation over $41 \%$ of the total harvested maize land. Furrow irrigation is still the main irrigation method in China, and accounted $86 \%$ of total WF of irrigated maize production in 2013. The study period witnessed an increasing WF of micro irrigated maize production, from zero to $7 \%$ of total WF related to irrigated maize production, with the expansion in the micro irrigation across the country. In most provinces, the WF per tonne of maize under micro irrigation was the smallest, followed by furrow irrigation and finally sprinkler irrigation. The WF per tonne of rain-fed maize was always larger than the WF of irrigated maize, due to a relatively lower yield level. Micro irrigation had the highest blue water fraction in the total WF.

\subsection{Maize-related WF of pork in China}

The fraction of maize in pig feed increased considerably over the period 2000-2013 (CFIA, 2013), with the number of pigs increasing by $14 \%$ but total maize consumption by pigs increasing by $68 \%$. The pork production rate (meat per animal) was stable over the period considered. The average 'virtual maize content' of pork in China increased by $46 \%$, from 2.8 in 2000 to $4.1 \mathrm{~kg} \mathrm{~kg}^{-1}$ in 2013 (Table 1). The increasing trend reflects the effects of the expansion in scale breeding of pigs that the occupation of which in the national swine cultivation increased from $9 \%$ to 50\% over 2000-2013 and rising demand of concentrated feed (Tian et al., 2016). Translating the maize content of pork to the underlying water consumption, we find that the average maize-related WF of pork increased by $7 \%$.

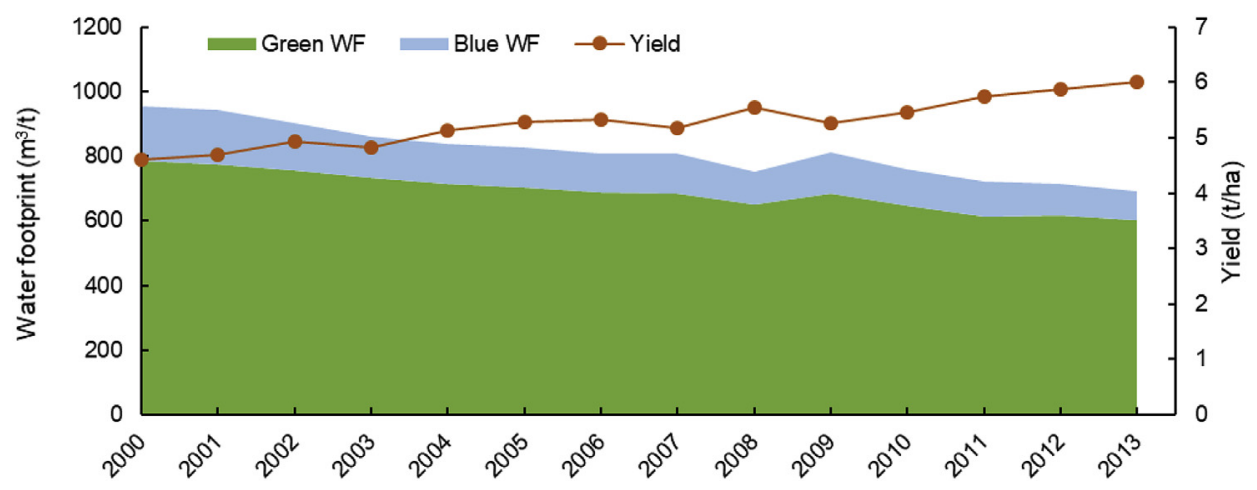

Fig. 3. National average water footprint per tonne of maize production and average maize yield in China over the period $2000-2013$. 

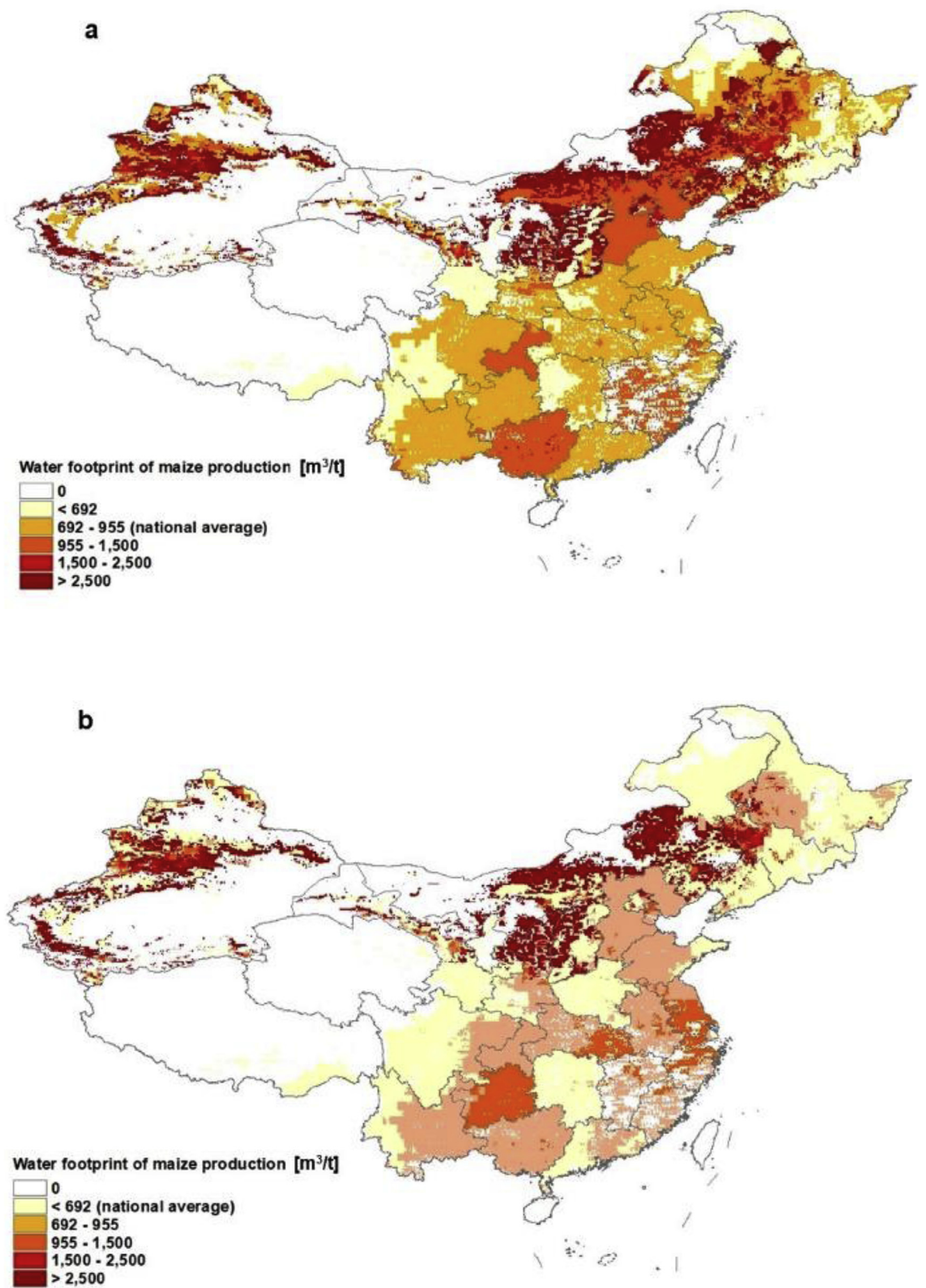

Fig. 4. The spatial distribution of the water footprint per tonne of maize across provinces in China in the years 2000 (a) and 2013 (b).

This rate of increase was less than $46 \%$ because of the reduction in the WF per tonne maize in the country (Fig. 3).

At provincial level, the maize-related WF of pork ranged between $1580 \mathrm{~m}^{3} \mathrm{t}^{-1}$ (Ningxia) and $3680 \mathrm{~m}^{3} \mathrm{t}^{-1}$ (Hebei). As shown in Fig. 5, the maize-related WF of pork was relatively high in eastern provinces, where most of the swine farms are located (Fig. 2). Twenty-one provinces had an increased maize-related WF per tonne of pork over the study period, with Shandong province having the sharpest increase (from 2230 to $3110 \mathrm{~m}^{3} \mathrm{t}^{-1}$ ), mainly due to the increased maize-feed per pig. 
Table 1

Maize consumption by pigs and maize-related water footprint (WF) of pork in China.

\begin{tabular}{|c|c|c|c|c|c|c|c|c|c|c|c|c|c|c|}
\hline & 2000 & 2001 & 2002 & 2003 & 2004 & 2005 & 2006 & 2007 & 2008 & 2009 & 2010 & 2011 & 2012 & 2013 \\
\hline Maize for feed for pigs $\left(10^{6} t\right)$ & 89 & 87 & 89 & 90 & 92 & 94.5 & 92.5 & 95.5 & 106 & 106 & 115 & 125 & 140 & 150 \\
\hline Pigs $\left(10^{6}\right.$ head $)$ & 416 & 420 & 418 & 414 & 421 & 433 & 419 & 440 & 463 & 470 & 465 & 469 & 476 & 474 \\
\hline Pork production rate $\left(\mathrm{kg} \mathrm{head}^{-1}\right)$ & 77 & 76 & 76 & 76 & 76 & 76 & 76 & 76 & 76 & 76 & 76 & 76 & 77 & 77 \\
\hline $\begin{array}{l}\text { Virtual maize content of pork } \\
\left(\mathrm{kg} \mathrm{kg}^{-1}\right)\end{array}$ & 2.8 & 2.7 & 2.8 & 2.8 & 2.9 & 2.9 & 2.9 & 2.8 & 3.0 & 2.9 & 3.2 & 3.5 & 3.8 & 4.1 \\
\hline Maize-related WF of pork $\left(\mathrm{m}^{3} \mathrm{t}^{-1}\right)$ & 2668 & 2551 & 2513 & 2444 & 2387 & 2357 & 2334 & 2289 & 2250 & 2381 & 2441 & 2515 & 2730 & 2860 \\
\hline
\end{tabular}
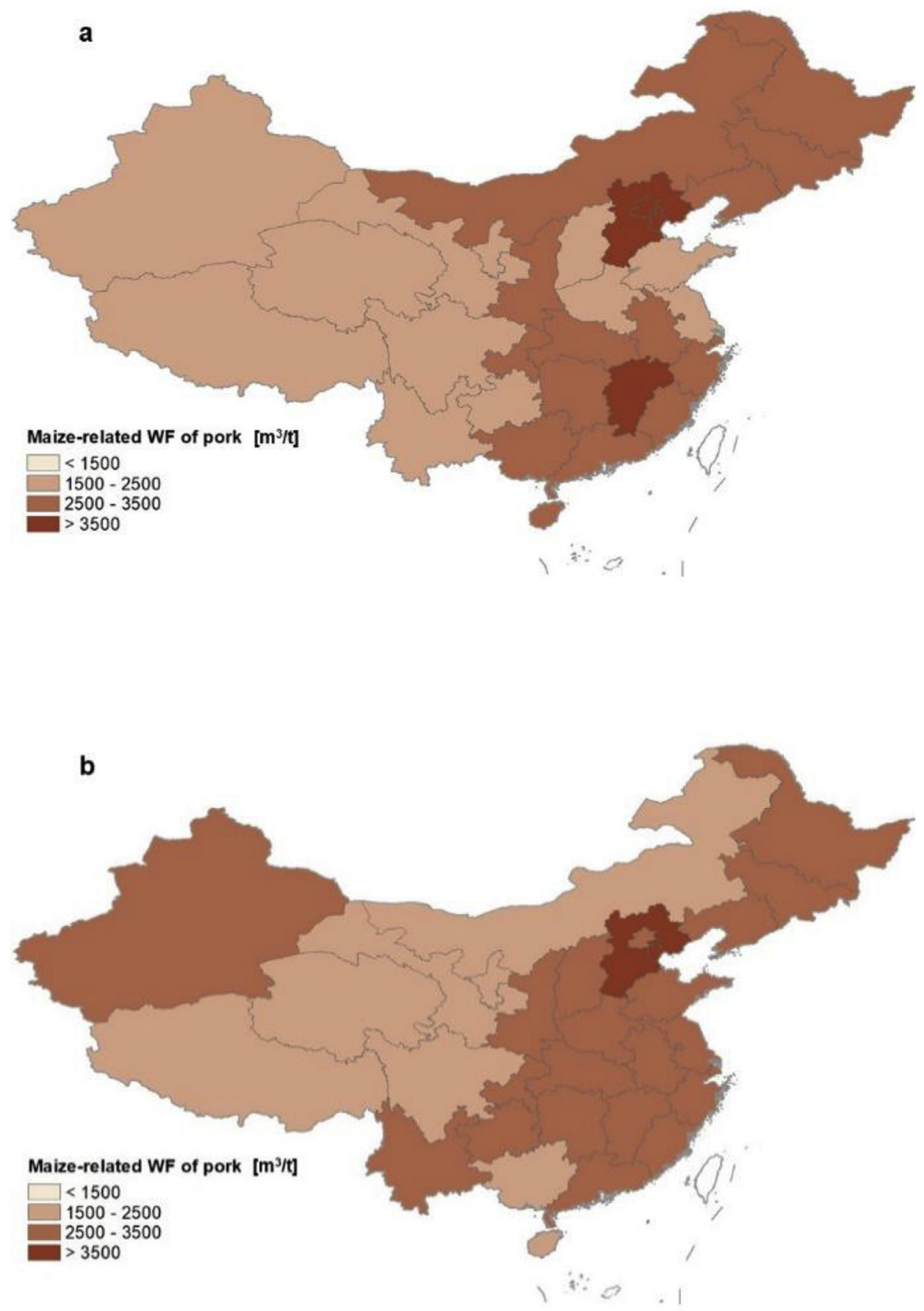

Fig. 5. The spatial distribution of maize-related water footprint per tonne of pork in the years 2000 (a) and 2013 (b). 


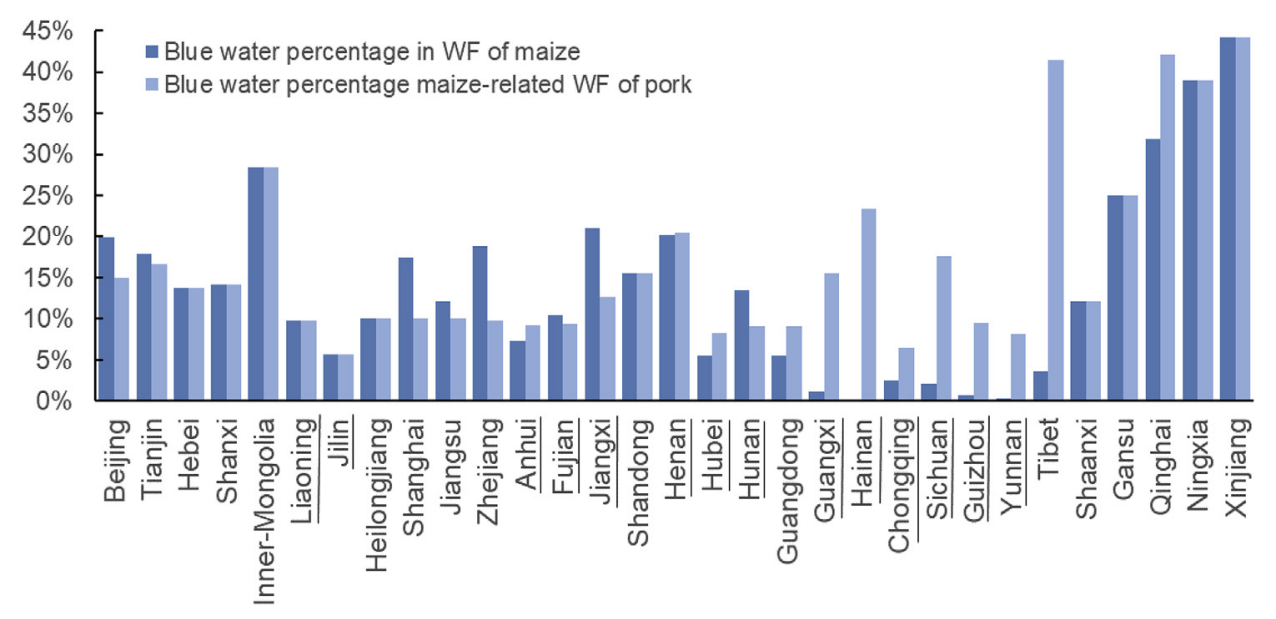

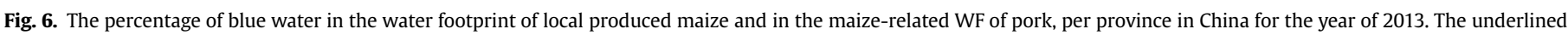
provinces are net exporters of pork. (For interpretation of the references to colour in this figure legend, the reader is referred to the Web version of this article.)

Fig. 6 shows, per province, for 2013, the blue water percentage in the maize-related WF of pork versus the blue water percentage in the WF of maize. Most exporting provinces of pork (most depending on imported maize) had a higher blue water fraction in the maize-related WF of pork than in the WF of locally produced maize. The main reason is that they imported maize from more water-scarce northern provinces where there are higher blue WF ratios in maize production. For example, Anhui, Hubei, Hunan and Chongqing province imported maize for their pigs from Northeastern China (Heilongjiang, Liaoning and Jilin) while Sichuan, Guizhou and Yunnan imported maize from Northern and Northwestern provinces.

\subsection{Virtual water flows related to maize in the two trade stages}

Over the period 2000-2013, maize trade from North to South China increased by a factor 2.2 (from 45 to 99 million $\mathrm{t} \mathrm{y}^{-1}$ ). In 2013, North-to-South maize trade was equivalent to $45 \%$ of China's total maize production. In that year, North China accounted for $86 \%$ of national maize production whereas the South accounted for $59 \%$ of national maize consumption.

The net VW flow related to trade in maize (trade stage TS1) has thus been from the water-scarce North to the water-rich South. The net maize-related North-to-South VW flow increased by $40 \%$ (from 43 to 61 billion $\mathrm{m}^{3} \mathrm{y}^{-1}$ ) (Fig. 7a). This maize-related VW flow increased less than the North-to-South trade of maize itself because of the decrease in WF per tonne of maize in this period (Fig. 3a). In 2013, Heilongjiang and Jilin provinces, both located in Northeast China, were the biggest net VW exporters in TS1, exporting 51\% of the gross inter-provincial VW flows in 2013 (see Fig. 8a). Hunan was the biggest net VW importer (with 10.2 billion $\mathrm{m}^{3} \mathrm{y}^{-1}$ of net VW import in 2013), driven by the province's use of maize for feed consumption while local maize production was low (see Fig. 2).

The second trade stage (TS2), the trade of pork, gives a very different picture. South China accounts for $59 \%$ of national total pork production and $60 \%$ of national pork consumption. The net trade of pork is from South to North China. As a result, also the VW flow related to trade in maize embodied in pork was from South to North China. This VW flow in TS2 is thus in the opposite direction to the VW flow in TS1. The VW flow from South to North in TS2 increased by $25 \%$ over the study period (from 4.8 to 6.1 billion $\mathrm{m}^{3}$ $\mathrm{y}^{-1}$ ) (Fig. 7b). This means that in TS2 about $10 \%$ of the water embodied in maize exports from North to South China returns in the form of pork. The net flow of the VW in the whole productionconsumption chain was 55 billion $\mathrm{m}^{3} \mathrm{y}^{-1}$ by 2013. There was a sharp increase in the size of the South-to-North VW flow in TS2 from year 2005-2006 due to the reduced pork production in a larger number of provinces (mostly located in the North) as a result of a severe pig blue ear disease outbreak in 2006 (CCG, 2007).

In 2013, ten provinces in the South were a net VW importer in TS1 but a net VW exporter in TS2 (Fig. 8). Hunan, the biggest VW importer in TS1, was the biggest VW exporter in TS2. Reversely, nine provinces in the North were a net VW exporter in TS1 but a net VW importer in TS2. This included Heilongjiang, the largest VW exporter in TS1. The amount of 'returning water' can be substantial, as shown by the case of Shanxi province in the North: the VW import of Shanxi in TS2 was equivalent to 63\% of the VW export in TS1. Still, the province has a net VW export related to maize trade, but much less than appears at first sight. Much of the water consumed in the province for producing export maize returns in (a)

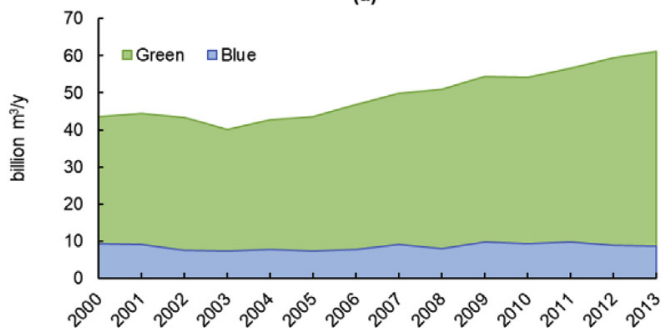

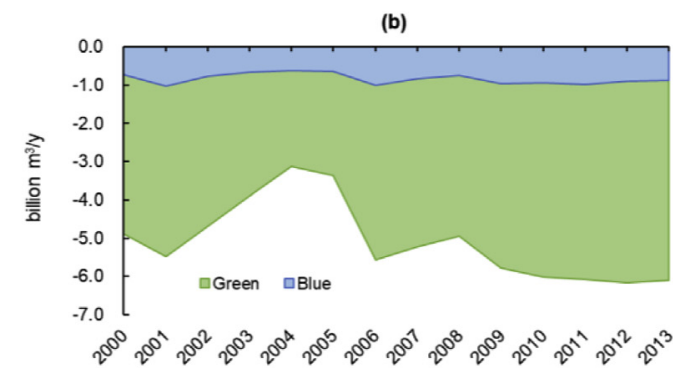

Fig. 7. Net virtual water flow from North to South China related to trade in maize (a) and related to trade in maize embodied in pork (b) over the period $2000-2013$. 

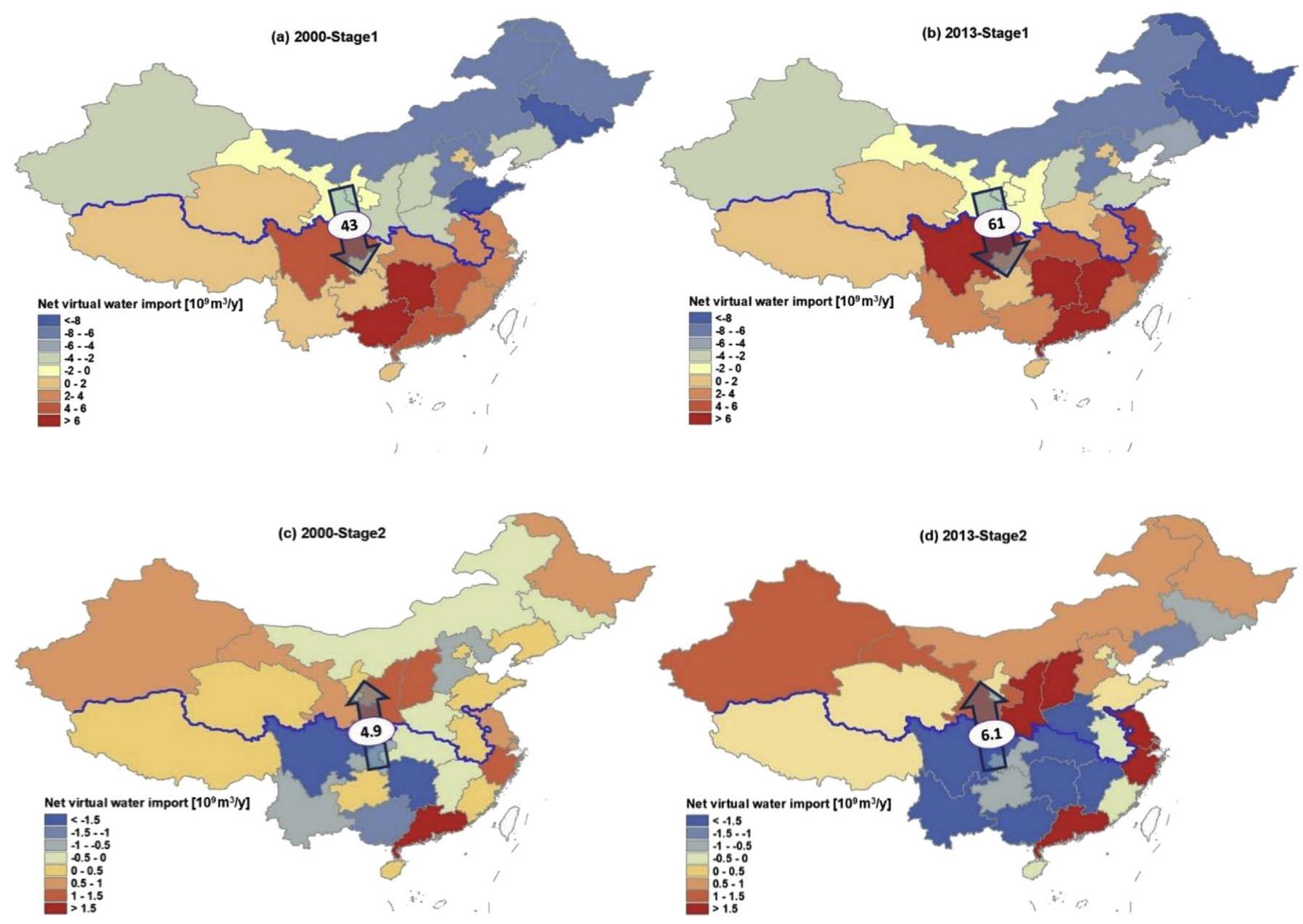

Fig. 8. Maize-related net virtual water imports per province in Trade Stage 1 in 2000 (a) and 2013 (b) and in Trade Stage 2 in 2000 (c) and 2013 (d). Arrows show the net virtual water flows between the North and South China.

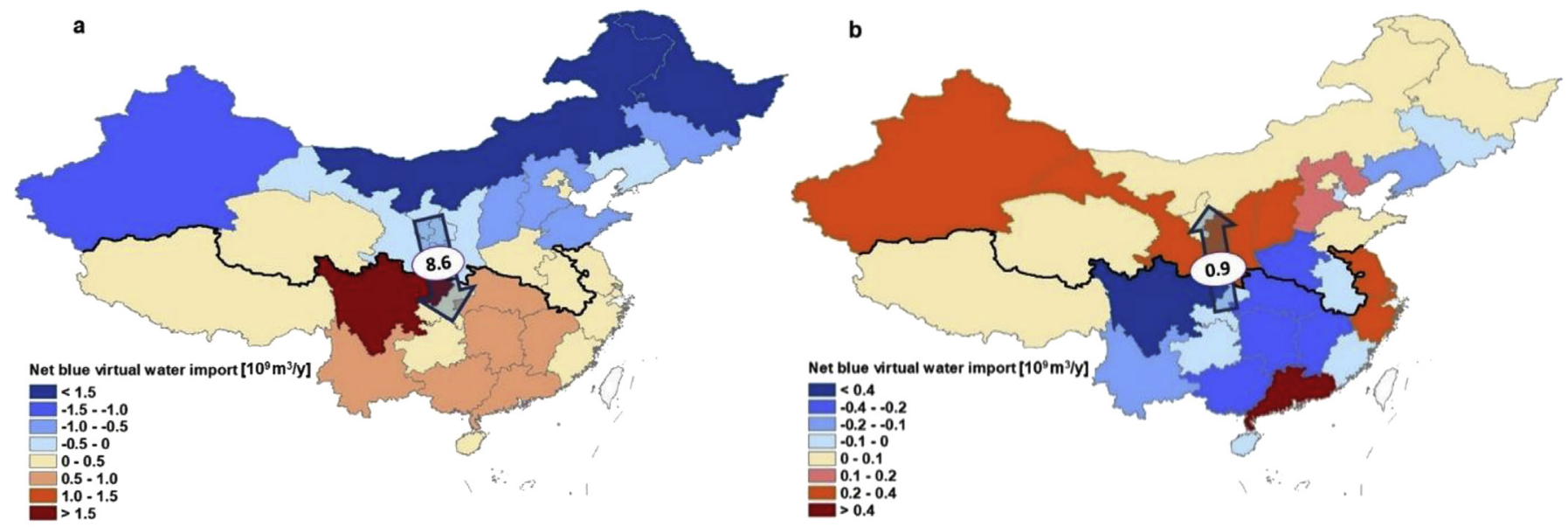

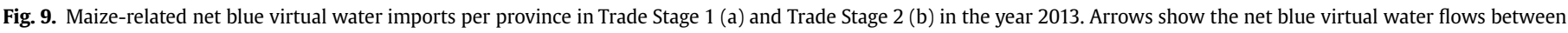
North and South China. (For interpretation of the references to colour in this figure legend, the reader is referred to the Web version of this article.)

the form of imported pork. Liaoning and Jilin province, two Northeastern provinces, had VW exports in both TS1 and TS2; these two provinces are expanding production bases of both maize (with a 1.8-time production increase over the study period) and swine (with doubled and 1.5 fold production increase in Liaoning and Jilin, respectively). 

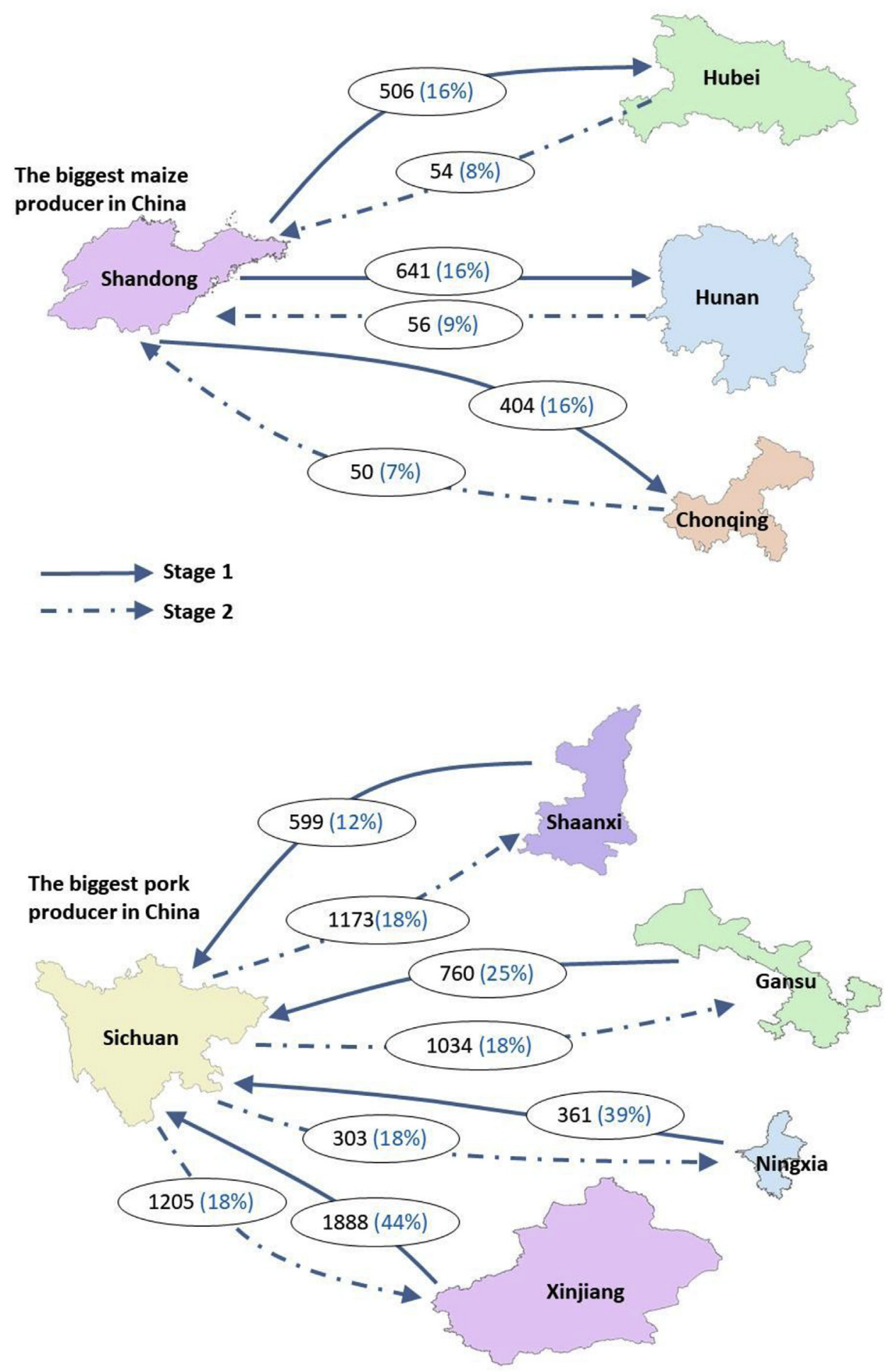

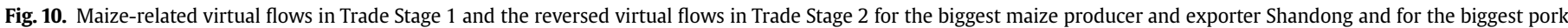

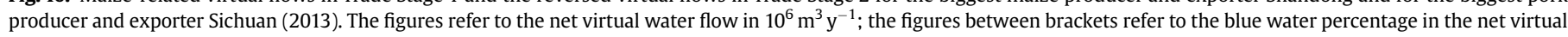
water flow. (For interpretation of the references to colour in this figure legend, the reader is referred to the Web version of this article.)

When we focus on blue water only, we find that the North-toSouth blue VW flow in TS1 decreased over the study period by $5 \%$ (from 9.1 to 8.6 billion $\mathrm{m}^{3} \mathrm{y}^{-1}$ ), while the South-to-North blue VW flow in TS2 increased by $23 \%$ (from 0.7 to 0.9 billion $\mathrm{m}^{3} \mathrm{y}^{-1}$ ). Most of the provinces with net blue VW export in TS1 are net blue VW importers in TS2 (Fig. 9), except for the north-eastern provinces of
Liaoning and Jilin, which together increasingly form China's key swine base and suffer moderate blue water scarcity (Zhao et al., 2018). In 2013, the total net blue VW export from Liaoning and Jilin over the two trade stages accounted for $49 \%$ and $64 \%$ of the total WF of local maize production, respectively.

In Fig. 10, we illustrate the reversed VW flows in TS1 and TS2 for 
the biggest maize producer (Shandong province) and the biggest pork producer (Sichuan province). About $11 \%$ of the VW flow from Shandong (in the North) to Hubei (in the South) in TS1 (maize trade) is returned in TS2 (pork trade); these 'return flows' in the form of pork are $9 \%$ for the maize trade from Shandong to Hunan, and $12 \%$ for the maize trade from Shandong to Chongqing. The pork exporting province of Sichuan exports a lot of VW embedded in pork, but also imports a lot of VW embedded in maize to feed the pigs. Considering the net effect of TS1 and TS2, Sichuan shows a net export of VW to Shaanxi and Gansu provinces (pork export being dominant), but a net import of VW from Ningxia and Xinjiang (maize import being dominant).

\subsection{Discussion}

\subsubsection{Sustainability of maize-related blue WFs and VW flows in China}

Following the approach for "WF sustainability assessment" by Hoekstra et al. (2011), we assess the impacts of maize production and consumption on blue water scarcity (BWS) and sustainability of maize-related blue WFs and VW flows in China. Blue WFs of maize production and maize related inter-provincial virtual water (VW) exports in both ST1 and ST2 were compared to the average local BWS levels at $30 \times 30$ arc minute grid level by Mekonnen and Hoekstra (2016). The BWS level was indicated as the ratio of the local blue WF to the total blue water availability. The blue water availability is the sum of locally generated blue water in a grid cell, which adopted the 80\%-natural-runoff-presumptive environmental flow standard (Richter et al., 2012) and the blue water flowing in from upstream grid cells (Mekonnen and Hoekstra, 2016). The presumptive environmental flow standards stand for a moderate level of protection with measurable changes in structure and minimal changes in ecosystem functions. The BWS values are classified into four levels: low $(\mathrm{BWS}<1.0)$, moderate $(1.0<$ BWS $<1.5)$, significant $(1.5<$ BWS $<2.0)$ and severe $(B W S>2.0)$ (Hoekstra et al., 2012).

Fig. 11 shows that more than half of the maize fields in Northern China was under severe BWS by the year 2013. Current results show that $67 \%$ of total blue WF in maize production contributed to severe BWS in China, which means severe unsustainable. Six in Eleven blue VW exporting provinces in ST1 had over 70\% of blue WF of maize production located in area under severe BWS. Over $90 \%$ of the blue WF in maize production in four provinces including Hebei, Shanxi, Shandong and Xinjiang were severe unsustainable. Maize production contributed to $27 \%, 16 \%, 13 \%$ and $13 \%$ of the overall severe BWS in Shanxi, Shandong, Hebei and Xinjiang, respectively (Mekonnen and Hoekstra, 2016; Hoekstra and Mekonnen, 2012). Without maize production, Henan province may relieve its overall BWS level from severe (BWS $=2.2$ ) to moderate $(B W S=1.6)$. As a result, $59 \%$ of the maize-related inter-provincial blue VW exports in ST1 was from maize fields under severe BWS (Fig. 11a). Xinjiang province can be identified as a hotspot in ST1 for urgent measures to reduce blue WFs in maize production, because it had $92 \%$ of severe unsustainable blue WF of maize production, $68 \%$ of total blue WF was for producing exported maize to other provinces and accounted for $21 \%$ of severe unsustainable maize-related interprovincial blue VW flows, however, only $17 \%$ of the blue VW exports returned back in ST2. The finding is consistent with Zhao et al. (2018). Whereas in ST2, majority of the maize-related blue VW exporting provinces (i.e. maize-related VW importers in ST1) were under low scarcity, however, only $12 \%\left(\sim 632\right.$ million $\left.\mathrm{m}^{3} \mathrm{y}^{-1}\right)$ of the severe unsustainable North-to-South blue VW flows in ST1 returned in ST2 (Fig. 11b). Liaoning and Jilin province, the two VW exporters in both ST1 and ST2 are the other two hotspots. By the year 2013, the severe unsustainable blue VW exports of Liaoning and Jilin meant $17 \%$ and $19 \%$ of total local blue water consumption in maize production, respectively. The percentages could keep increasing with the current expanding trends in production of both maize and swine (see section 3.3).

Urgent actions are called for reducing the severe unsustainable blue WF in maize production and associated blue VW flows so that mitigating the severe BWS in the hotspots. Four key strategies can be taken into consideration for more sustainable water consumption related to China's maize (Hoekstra and Mekonnen, 2016): (i) Reducing the blue WF in current water scarce maize fields by setting and reaching the blue WF benchmarks with smart field managements (e.g. drip irrigation combined with synthetic mulching) (Chukalla et al., 2015; Zhuo and Hoekstra, 2017; Nouri et al., 2019) or planting more water-saving and higher-waterproductive varieties; (ii) Increasing self-sufficiency degree of feed crops in swine-based provinces under low water scarcity like Hunan, Hubei and Jiangxi provinces; (iii) Reducing the reliance on imports from water scarce regions while increase the production and exports in places with lower water scarcity and higher water productivities (Hoekstra and Mekonnen, 2016); (iv) enhancing the international trade of feed crops from water-abundant countries while ensuring the staple food self-sufficiency as in governmental goals.

\subsubsection{Burden shifting}

The results illustrate that mapping of VW flows along a feedmeat supply chain helps to better understand the impact of a two-step supply chain on the spatial water use pattern in a country. The case study for China reveals that the water embodied in the maize traded from the water-scarce North to feed pigs in the more water-abundant South partly returned to the North in the form of traded pork. However, only about $10 \%$ of the embedded water in the maize exports from the North returned embedded in imported pork. Despite the trade of pork back to the North, the environmental burden shifting remains from the South to the North.

\subsubsection{Uncertainties and limitations}

A major limitation in the study was the absence of statistics regarding the inter-provincial trade network of specific agricultural products for China. The method of trade network simulation, assumptions in the precondition of trade flow and uncertainties embodied in the unit WF per traded product generate the disparity in the VW flow estimations (Liu et al., 2018a,b). The current study applies the bottom-up approach according to the food balance per province. The order of magnitude and main directions in the maizerelated VW flows in TS1 and TS2, which is dominated by the trade in pork, are consistent with available studies based on either the bottom-up approach (Ma et al., 2006; Dalin et al., 2014) or topdown approach based on multi-regional input-output tables (e.g. Zhao et al., 2015). In current simulations, the local consumption of local production is assumed as being priority compared to exports, while exports can be prioritized compared to local consumption of maize and pork production in one provinces driven by economic benefits. However, we made the best assumptions in making the most of accessible data, following the previous widely acceptable and cited studies like Ma et al. (1998) and Dalin et al. (2014). The top VW exporters are consistent with Dalin et al. (2014), although the priorities of international trades in meeting the demand are different. Therefore, the shown VW flow patterns and magnitudes are comparable to the available reports based on similar assumptions and approaches. There must be over- or under-estimation in the trade balances per province according to the food balance assumptions. For local studies focusing on smaller regions than provincial scale, validation and modification of the current VW trade modelling based on surveys or accessible official data on transfers 

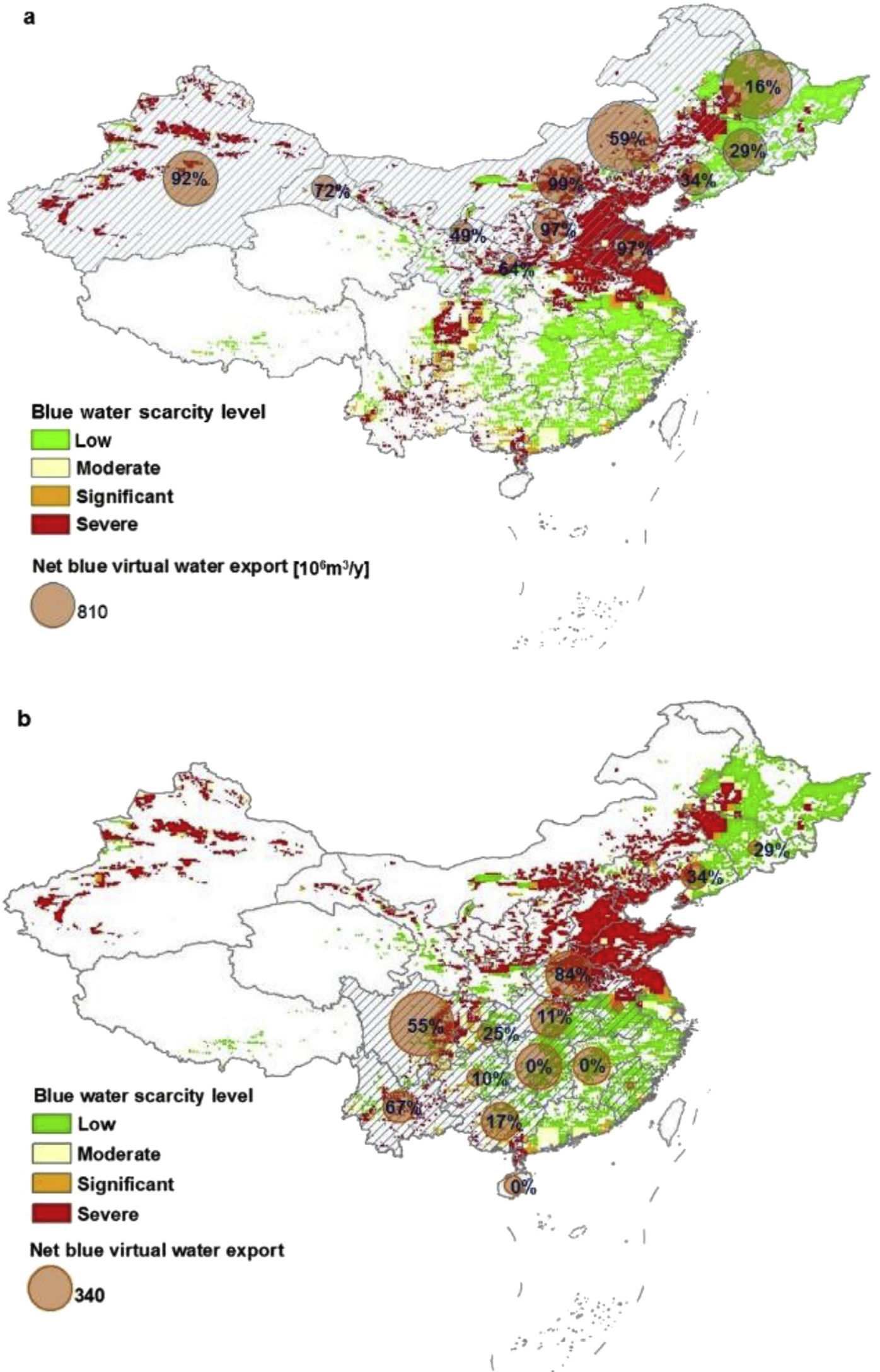

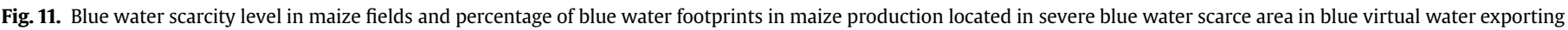
provinces in (a) ST1 and (b) ST2 in China 2013. (For interpretation of the references to colour in this figure legend, the reader is referred to the Web version of this article.) 
of crop is crucial for setting relative local water policies. One may suggest to compare to results based on the top-down approaches. However, the main difference between the bottom-up and topdown approach is that the MRIO modelling cannot downscale from the whole agricultural sector into specific individual products (Feng et al., 2011; Zhao et al., 2018). While the same main directions of the inter-provincial VW flows still tell the feasibility of the current methodology and results.

Regarding the uncertainties in the WF accounting for crop production, Kersebaum et al. (2016) identified, through winter wheat in European environment as the case, that the variation among calculated unit WFs by different crop growth models (including the AquaCrop) was 15\%-49\%, and the discrepancy in yield simulations dominated the differences in WF results rather than that in simulated ET. The current study calibrates yield simulations of maize based on provincial statistics per year. Zhuo et al. (2014) tested effects of uncertainties in key input variables on the crop WF accounting results via the study case on major crops in the Yellow River Basin, and concluded an uncertainty range of $\pm 30 \%$ in the simulated unit WF of crops through the CropWat method. We compare the current results on unit WF of maize production per province to the estimations in three studies with varied data sources and models (Dalin et al., 2014; Zhuo et al., 2016a; Mekonnen and Hoekstra, 2011) as shown in Fig. 12. There are 87\% of the tested figures with the acceptable deviations less than 30\% to the previous studies. At national average level, the current unit WF of maize production in China is $10 \%$ higher than the records by Mekonnen and Hoekstra (2011) who calibrated the simulated yield based on national average level. We used the same input data sources as in Zhuo et al. (2016a), however with the consideration of different irrigation method. As a result, the national average unit WFs of maize differ in the range of $-6 \%-5 \%$, while the current blue WF rates in the green-blue WF in the current study are 0.8-1.9 times higher, which shows the effects of the differences in modelling settings.

Assumptions have to be made in the current simulations of the VW networks with the data limitations. Firstly, the maize consumption level per capita was assumed the same across provinces and the differences in diets among rural and urban residents were ignored. Secondly, in the simulations for VW flows in the TS2, we assume a unit maize feeding concentration per livestock without available detailed information on animal-specific maize feeding level for China. The mentioned assumptions may result in the overor under-estimation on the provincial trade balances so that affect

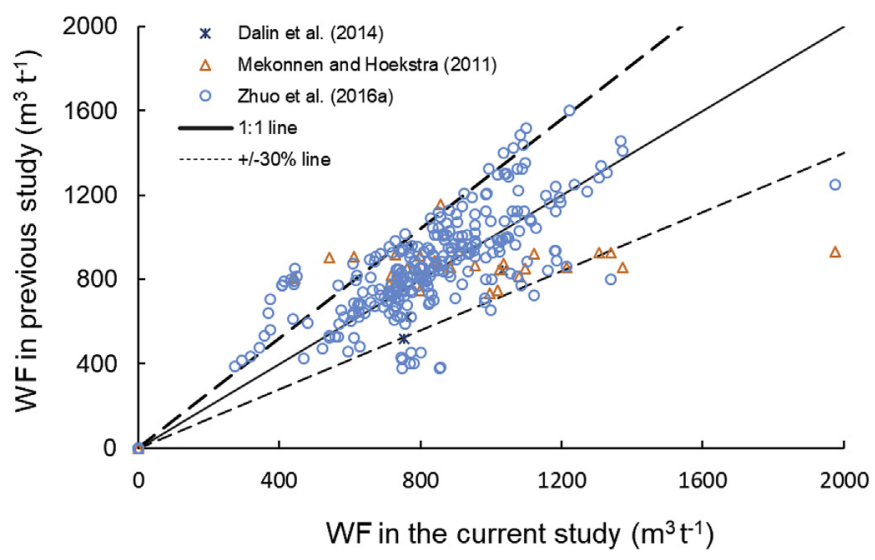

Fig. 12. The water footprint (WF) per tonne of maize at provincial level in China in the current study compared with estimations from previous studies. Figures are for the year 2007 in Dalin et al. (2014); the year 2000 in Mekonnen and Hoekstra (2011) and the annual values for 2000-2008 in Zhuo et al. (2016a). the corresponding inter-provincial VW trade matrixes. According to the identification by Tamea et al. (2014), population, gross domestic product and geographical distances between trade partners were the major driving factors in global VW fluxes, which were mainly considered in current simulations. Therefore, given the broad comparisons with available information and knowledge, we believe that the current results on the main directions in the network of VW flows over the extended production-consumption chain of maize in China are acceptable and solid.

\subsubsection{Implications of the new policies regarding reallocation of} animal production to the North for water resources management

China's governmental plan for the pork industry for the period 2016-2020 (MOA, 2016) aims to increase the pork production by 0.14 billion $\mathrm{t}^{-1}$ to maintain a high self-sufficiency. In the plan, four North-eastern provinces (Liaoning, Jilin, Heilongjiang and Inner Mongolia), which are the biggest net VW exporters related to maize trade (TS1), are designated as the future pork base, with $1-2 \%$ of production increase per year, given the relatively abundant land and feed availabilities, but without considering impacts on local water security. Such pork industry expansion could generate income, but will undoubtedly increase local feed production demand and associated water consumption, thus increasing local water scarcity levels. Besides, the planned intensification in both maize and pork production in the North-eastern provinces may accelerate nitrogen $(\mathrm{N})$ and phosphorus $(\mathrm{P})$ pollution of groundwater and streams (Sun et al., 2018; Wang et al., 2017, 2018a, 2018b). Bai et al. (2018) show that many regions in the Liaoning, Jilin and Heilongjiang provinces have already become polluted with $\mathrm{N}$ and $\mathrm{P}$ because of the intensive agricultural activities. This will worsen if more pig production moves to these provinces.

\section{Conclusion}

The study maps and links, for the first time, the VW flows related to the trade of a feed crop (TS1) and the trade of an animal product based on this feed (TS2), taking the water-for-maize-forpig-for-pork example in China over the period 2000-2013 as a study case. Although there was visible reduction in WF per unit mass of maize (by 23\%), the net VW flow related to maize trade (TS1) from the water-scarce North to the more water-abundant South of China grew by $40 \%$, related to the doubling of the trade volume over the study period. In the reversed direction, the net VW flow from South to North related to maize embedded in traded pork (TS2), increased by $25 \%$ over the same period. Regarding blue VW flows specifically, North-to-South blue VW flows decreased by $5 \%$ in TS1, while South-to-North blue VW flows increased by $23 \%$ in TS2.

With this assessment, we illustrate the complexity of environmental burden shifting through trade in the case of an animal product supply chain. The current case for Chinese pork reveals that the environmental burden related to pork consumption in the South is shifted to the North, because of the import of feed maize from the North. However, not all feed maize imported from the North to produce pork in the South can be accounted to pork consumption in the South, since some of the pork produced in the South with feed from the North is traded back to the North. Enhancing both feed and pork production in northern regions as in governmental plans may boost local income but will be at the cost of intensified water scarcity.

\section{Declaration of competing interest}

The authors declare that they have no known competing financial interests or personal relationships that could have 
appeared to influence the work reported in this paper.

\section{Acknowledgements}

This work was financially supported by the National Key Research and Development Plan (2018YFF0215702), National Natural Science Foundation of China (51809215), the Natural Science Foundation of Shaanxi Province (2018JQ4020), the West Light Talent Program of the Chinese Academy of Sciences (XAB2017B03), and the 111 Project (No. B12007).

\section{References}

Allan, J.A., 2003. Virtual water - the water, food, and trade nexus: useful concept or misleading metaphor? Water Int. 28 (1), 4-11.

Allen, R.G., Pereira, L.S., Raes, D., Smith, M., 1998. Crop Evapotranspiration: Guidelines for Computing Crop Water Requirements, FAO Irrigation and Drainage Paper 56. FAO, Rome, Italy.

Bai, Z., Lu, J., Zhao, H., Velthof, G.L., Oenema, O., Chadwick, D., Williams, J.R., Jin, S., Liu, H., Wang, M., Strokal, M., Kroeze, C., Hu, C., Ma, L., 2018. Designing vulnerable zones of nitrogen and phosphorus transfers to control water pollution in China. Environ. Sci. Technol. 52 (16), 8987-8988.

Batjes, N.H., 2012. ISRIC-WISE Derived Soil Properties on a 5 by 5 Arc-Minutes Global Grid (Ver. 1.2). ISRIC, Wageningen, The Netherlands.

Cao, X., Wu, P., Wang, Y., Zhao, X., Li, S., 2011. Application of virtual water trade theory in inter-regional grain allocation and transportation in China. Afr. J. Biotechnol. 10 (80), 18463-18471.

CCG, 2007. Ministry of Agriculture: the First Batch of Highly Pathogenic Pig Blue Ear Disease Vaccines Put into Use. China Central Government. http://www.gov.cn/ jrzg/2007-06/13/content_647927.htm. (Accessed 8 October 2018).

CFIA, 2013. China Feed Industry Yearbook 2011-2012. China Feed Industry Association, Beijing, China.

Chukalla, A., Krol, M., Hoekstra, A.Y., 2015. Green and blue water footprint reduction in irrigated agriculture: effect of irrigation techniques, irrigation strategies and mulching. Hydrol. Earth Syst. Sci. 19, 4877-4891.

Dalin, C., Wada, Y., Kastner, T., Puma, M.J., 2017. Groundwater depletion embodied in international food trade. Nature 543, 700-704.

Dalin, C., Rodríguez-Iturbe, I., 2016. Environmental impacts of food trade via resource use and greenhouse gas emissions. Environ. Res. Lett. 11, 035012.

Dalin, C., Hanasaki, N., Qiu, H.G., Mauzerall, D.L., Rodriguez-Iturbe, I., 2014. Water resources transfers through Chinese interprovincial and foreign food trade. Proc. Natl. Acad. Sci. U.S.A. 111 (27), 9774-9779.

Dalin, C., Konar, M., Hanasaki, N., Rinaldo, A., Rodríguez-Iturbe, I., 2012. Evolution of the global virtual water trade network. Proc. Natl. Acad. Sci. U.S.A. 99 (16), 5989-5994.

Dijkshoorn, K., van Engelen, V., Huting, J., 2008. Soil and Landform Properties for LADA Partner Countries. ISRIC-World Soil Information and FAO, Wageningen, The Netherlands.

D'Odorico, P., Carr, J., Dalin, C., Dell'Angelo, J., Konar, M., Laio, F., Ridofi, L., Rosa, L., Suweis, S., Tamea, S., Tuninetti, M., 2019. Global virtual water trade and the hydrological cycle: patterns, drivers, and socio-environmental impacts. Environ. Res. Lett. 14, 053001.

Dong, H., Geng, Y., Fujita, T., Fujii, M., Hao, D., Yu, X., 2014. Uncovering regional disparity of China's water footprint and inter-provincial virtual water flows. Sci. Total Environ. 500-501, 120-130.

FAO, 2018. FAOSTAT On-Line Database. http://faostat.fao.org. (Accessed June 2018).

Feng, K., Chapagain, A., Suh, S., Pfister, S., Hubacek, K., 2011. Comparison of bottomup and top-down approaches to calculating the water footprints of nations. Econ. Syst. Res. 23 (4), 371-385.

Feng, K., Hubacek, K., Pfister, S., Yu, Y., Sun, L., 2014. Virtual scarce water in China. Environ. Sci. Technol. 48, 7704-7713.

Gao, S., Guo, G., Dai, X., 2014. Research of inter-provincial grain transport costs based on GIS network analyst. Logistics Sci-Tech 5, 135-139.

Guan, D., Hubacek, K., 2007. Assessment of regional trade and virtual water flows in China. Ecol. Econ. 61 (1), 159-170.

Hanasaki, N., Inuzuka, T., Kanae, S., Oki, T., 2010. An estimation of global virtual water flow and sources of water withdrawal for major crops and livestock products using a global hydrological model. J. Hydrol 384 (3-4), 232-244.

Hansen, J.A., 2007. SWINE NUTRITION GUIDE. North Carolina State University. Available at: https://projects.ncsu.edu/project/swine_extension/nutrition/ nutritionguide/default.htm.

Harris, I., Jones, P.D., Osborn, T.J., Lister, D.H., 2014. Updated high-resolution grids of monthly climatic observations - the CRU TS3.10 Dataset. Int. J. Climatol. 34 (3), 623-642.

Hoekstra, A.Y., 2017. Water footprint assessment: evolvement of a new research field. Water Resour. Manag. 31 (10), 3061-3081.

Hoekstra, A.Y., Mekonnen, M.M., 2012. The water footprint of humanity. Proc. Natl. Acad. Sci. U.S.A. 109 (9), 3232-3237.

Hoekstra, A.Y., Mekonnen, M.M., 2016. Imported water risk: the case of the UK. Environ. Res. Lett. 11, 055002.

Hoekstra, A.Y., Mekonnen, M.M., Chapagain, A.K., Mathews, R.E., Richter, B.D., 2012.
Global monthly water scarcity: blue water footprints versus blue water availability. PLoS One 7 (2), e32688.

Hoekstra, A.Y., Chapagain, A.K., Aldaya, M.M., Mekonnen, M.M., 2011. The Water Footprint Assessment Manual: Setting the Global Standard. Earthscan, London, UK.

Hsiao, T.C., Heng, L., Steduto, P., Rojas-Lara, B., Raes, D., Fereres, E., 2009. AquaCropthe FAO crop model to simulate yield response to water: III. Parameterization and testing for maize. Agron. J. 101 (3), 448-459.

Karandish, F., Hoekstra, A.Y., 2017. Informing national food and water security policy through water footprint assessment: the case of Iran. Water 9 (11), 831

Kersebaum, K.C., Kroes, J., Gobin, A., Takác, J., Hlavinka, P., Trnka, M., Ventrella, D., Giglio, L., Ferrise, R., Moriondo, M., Marta, A.D., Luo, Q., Eitzinger, J., Mirschel, W., Weigel, H.-J., Manderscheid, R., Hoffmann, M., Nejedlik, P., Iqbal, M.A., Hösch, J., 2016. Assessing uncertainties of water footprints using an ensemble of crop growth models on winter wheat. Water 8, 571.

Konar, M., Dalin, C., Suweis, S., Hanasaki, N., Rinaldo, A., Rodríguez-Iturbe, I., 2011. Water for food: the global virtual water trade network. Water Resour. Res. 47, W05520.

Lenzen, M., Moran, D., Bhaduri, A., Kanemoto, K., Bekchanov, M., Geschke, A., Foran, B., 2013. Ecol. Econ. 94, 78-85.

Liu, J., Hull, V., Batistella, M., DeFries, R., Dietz, T., Fu, F., Hertel, T.W., Izaurralde, R.C. Lambin, E.F., Li, S., Martinelli, L.A., McConnell, W.J., Moran, E.F., Naylor, R. Ouyang, Z., Polenske, K.R., Reenberg, A., de Miranda Rocha, G., Simmons, C.S., Verburg, P.H., Vitousek, P.M., Zhang, F., Zhu, C., 2013. Framing sustainability in a telecoupled world. Ecol. Sci. 18 (2), 26.

Liu, J.G., Zehnder, A.J.B., Yang, H., 2008. Historical trends in China's virtual water trade. Water Int. 32 (1), 78-90.

Liu, W., Antonelli, M., Kummu, M., Zhao, X., Wu, P., Liu, J., Zhuo, L., Yang, H., 2018a. Savings and losses of global water resources in food-related virtual water trade. Wiley Interdiscip. Rev. Water e1320.

Liu, W., Yang, H., Liu, Y., Kummu, M., Hoekstra, A.Y., Liu, J., Schulin, R., 2018b. Water resources conservation and nitrogen pollution reduction under global food trade and agricultural intensification. Sci. Total Environ. 633, 1591-1601.

Ma, J., Hoekstra, A.Y., Wang, H., Chapagain, A.K., Wang, D., 2006. Virtual versus real water transfers within China. Philos. Trans. R. Soc. B 361 (1469), 835-842.

Mekonnen, M.M., Hoekstra, A.Y., 2016. Four billion people facing severe water scarcity. Sci. Adv. 2, e1500323.

Mekonnen, M.M., Hoekstra, A.Y., 2012. A global assessment of the water footprint of farm animal products. Ecosystems 15, 401-415.

Mekonnen, M.M., Hoekstra, A.Y., 2011. The green, blue and grey water footprint of crops and derived crop products. Hydrol. Earth Syst. Sci. 15 (5), 1577-1600.

MOA, 2016. National Plan for Pig Industry Development (2016-2020). Ministry of Agriculture and Rural Affairs, Beijing, China.

NASMG, 2010. Surveying and Mapping Data Sharing Network. http://sms.webmap. cn/default.asp.

NBSC, 2018. National Data. National Bureau of Statistics, Beijing, China. http://data. stats.gov.cn/. (Accessed June 2018).

Nouri, H., Stokvis, B., Galindo, A., Blatchford, M., Hoekstra, A.Y., 2019. Water scarcity alleviation through water footprint reduction in agriculture: the effect of soil mulching and drip irrigation. Sci. Total Environ. 653, 241-252.

Novo, P., Garrido, A., Varela-Ortega, C., 2009. Are virtual water "flows" in Spanish grain trade consistent with relative water scarcity? Ecol. Econ. 68, 1454-1464.

Pace, M.L., Gephart, J.A., 2017. Trade: a driver of present and future ecosystems. Ecosystems 20, 44-53.

Portmann, F.T., Siebert, S., Doll, P., 2010. MIRCA2000-Global monthly irrigated and rainfed crop areas around the year 2000: a new high-resolution data set for agricultural and hydrological modeling. Glob. Biogeochem. Cycles 24, GB1011.

Raes, D., Steduto, P. Hsiao, T.C., Fereres, E., 2009. AquaCrop-the FAO crop model to simulate yield response to water: II. Main algorithms and software description. Agron. J. 101 (3), 438-447.

Richter, B.D., Davis, M., Apse, C., Konrad, C., 2012. A presumptive standard for environmental flow protection. River Res. Appl. 28 (8), 1312-1321.

Steduto, P., Hsiao, T.C., Raes, D., Fereres, E., 2009. AquaCrop-the FAO crop model to simulate yield response to water: I. Concepts and underlying principles. Agron. J. 101 (3), 426-437.

Sun, J., Mooney, H., Wu, W., Tang, H., Tong, Y., Xu, Z., Huang, B., Cheng, Y., Yang, X. Wei, D., Zhang, F., Liu, J., 2018. Importing food damages domestic environment: evidence from global soybean trade. Proc. Natl. Acad. Sci. U.S.A. 115 (21), 5415-5419.

Sun, S.K., Yin, Y.L., Wu, P.T., Wang, Y.B., Luan, X.B., Li, C., 2019. Geographical evolution of agricultural production in China and its effects on water stress economy, and the environment: the virtual water perspective. Water Resour. Res. 55 (5), 4014-4029.

Tamea, S., Carr, J.A., Laio, F., Ridolfi, L., 2014. Drivers of the virtual water trade. Water Resour. Res. 50, 17-28.

Tian, W., Yao, Q., Wu, X., 2016. Study on the Dynamic relationship between pigs scale breeding change and price fluctuation in China. Price: Theory Pract. 2, 81-84.

Verma, S., Kampman, D.A., van der Zaag, P., Hoekstra, A.Y., 2009. Going against the flow: a critical analysis of inter-state virtual water trade in the context of India's National River Linking Program. Phys. Chem. Earth 34, 261-269.

Wang, M., Kroeze, C., Strokal, M., Ma, L., 2017. Reactive nitrogen losses from China's food system for the shared socioeconomic pathways (SSPs). Sci. Total Environ. 605-606, 884-893.

Wang, M., Ma, L., Strokal, M., Ma, W., Liu, X., Kroeze, C., 2018a. Hotspots for nitrogen 
and phosphorus losses from food production in China: a county-scale analysis Environ. Sci. Technol. 52 (10), 5782-5791.

Wang, M., Ma, L., Strokal, M., Chu, Y., Kroeze, C., 2018b. Exploring nutrient management options to increase nitrogen and phosphorus use efficiencies in food production of China. Agric. Syst. 163, 58-72.

Wang, X., Hui, B., Zhou, W., Chen, Z., Zhang, D., 2014. Comparative analysis of drought in Guizhou from July to August between the year of 2011 and 2013 and the effect on agriculture. Tianjin Agric. Sci. 20 (11), 118-124.

Wiedmann, T., Lenzen, M., 2018. Environmental and social footprints of international trade. Nat. Geosci. 11, 314-321.

Wu, P., Zhao, X., Cao, X., Hao, S., 2010. Status and thoughts of Chinese "agricultural north-to-south water diversion virtual engineering". Trans. Chin. Soc. Agric Eng. 26 (6), 1-6.

Yang, H., Wang, L., Abbaspour, K.C., Zehnder, A.J.B., 2006. Virtual water trade: an assessment of water use efficiency in the international food trade. Hydrol. Earth Syst. Sci. 10, 443-454.

Zhang, C., Anadon, L., 2014. A multi-regional input-output analysis of domestic virtual water trade and provincial water footprint in China. Ecol. Econ. 100, 159-172.

Zhao, D., Tang, Y., Liu, J., Tillotson, M.R., 2017. Water footprint of Jing-Jin-Ji urban agglomeration in China. J. Clean. Prod. 167, 919-928.

Zhao, D., Hubacek, K., Feng, K., Sun, L., Liu, J., 2019. Explaining virtual water trade: spatial-temporal analysis of the comparative advantage of land, labor and water in China. Water Res. 153, 304-314.

Zhao, X., Liu, J., Yang, H., Duarte, R., Tillotson, M.R., Hubacek, K., 2016. Burden shifting of water quantity and quality stress from megacity Shanghai. Water Resour. Res. 52, 6916-6927. https://doi.org/10.1002/2016WR018595.

Zhao, X., Liu, J.G., Liu, Q.Y., Tillotson, M.R., Guan, D., Hubacek, K., 2015. Physical and virtual water transfers for regional water stress alleviation in China. Proc. Natl. Acad. Sci. U.S.A. 112 (4), 1031-1035.

Zhao, X., Li, Y., Yang, H., Liu, W., Tillotson, M.R., Guan, D., Yi, Y., Wang, H., 2018. Measuring scarce water saving from interregional virtual water flows in China. Environ. Res. Lett. 13, 054012.

Zhuo, L., Mekonnen, M.M., Hoekstra, A.Y., 2014. Sensitivity and uncertainty in crop water footprint accounting: a case study for the Yellow River basin. Hydrol Earth Syst. Sci. 18, 2219-2234.

Zhuo, L., Mekonnen, M.M., Hoekstra, A.Y., 2016a. The effect of inter-annual variability of consumption, production, trade and climate on crop-related green and blue water footprints and inter-regional virtual water trade: a study for China (1978-2008). Water Res. 94, 73-85.

Zhuo, L., Mekonnen, M.M., Hoekstra, A.Y., Wada, Y., 2016b. Inter- and intra-annual variation of water footprint of crops and blue water scarcity in the Yellow River basin (1961-2009). Adv. Water Resour. 87, 29-41. 